\title{
PKM Kelompok Tani Ibu-Ibu PKK Kelurahan Pandu Kecamatan Bunaken Tentang Pemanfaatan Fungisida Nabati Dalam Peningkatan Produksi Tanaman Pertanian
}

\author{
Stella Deiby Umboh ${ }^{1 *}$, Henny Lieke Rampe ${ }^{1}$ \\ 1Jurusan Biologi, Fakultas Matematika Dan Ilmu Pengetahuan Alam \\ Universitas Sam Ratulangi \\ *Penulis Korespondensi, Stella D. Umboh Jurusan Biologi FMIPA Universitas Sam Ratulangi Manado 95115. \\ Email: stellaumboh@unsrat.ac.id
}

\begin{abstract}
ABSTRAK
Fungisida nabati adalah salah satu alternatif penyelesaian kerusakan dan gangguan yang diakibatkan oleh hama dan penyakit tumbuhan di lahan-lahan pertanian yang penggunaannya mudah, efisien, murah, dan ramah lingkungan. Dalam menanggulangi hama dan penyakit diareal pertanian, maka petani banyak sekali memanfaatkan pestisida sintetik tanpa menyadari dampak residu yang ditimbulkannya dan inilah yang menjadi faktor kelemahan yang sering dijumpai dikalangan petani yang ada di Kelurahan Pandu. Selain itu pula kurangnya pengetahuan mereka tentang pemanfaatan fungisida nabati sebagai solusi alternatif pilihan lain dalam pengendalian organisme pengganggu tanaman pertanian. PKM ini memiliki tujuan dan target khusus yang ingin dicapai yaitu peningkatan pengetahuan serta keterampilan Petani dan Ibu-Ibu PKK dalam pemanfaatan fungisida nabati dalam meningkatkan produksi tanaman pisang. Metode yang digunakan dalam PKM ini adalah bentuk penyuluhan dan pelatihan (ceramah) serta praktek pembuatan fungisida nabati (simulasi). Kegiatan PKM ini dilaksanakan selama kurang lebih 8 bulan. Terjadi peningkatan pengetahuan dan pemahaman petani dan Ibu-Ibu PKK tentang dampak negatif dari pestisida sintetik bagi lingkungan dan manusia serta pemanfaatan fungisida nabati dalam meningkatkan produksi tanaman pisang, yang dibuktikan dengan hasil yang diperoleh dari kegiatan pretest dan posttest, dimana setelah selesai pemberian materi pada kegiatan PKM (Posttest) maka dari 37 orang peserta sudah tidak ada lagi peserta yang mendapatkan nilai di bawah $50(0.00 \%)$ dibandingkan pada saat sebelum kegiatan PKM (Pretest), dimana nilai persentase pada interval nilai 0-50 sebesar 97.3\%. Terjadi peningkatan keterampilan Petani dan Ibu-Ibu PKK dalam pembuatan fungisida nabati sebagai salah satu alternatif solusi pengendalian penyakit layu tanaman pisang akibat serangan jamur pathogen Fusarium oxysporum, yang dibuktikan dengan antusiasnya peserta mengikuti kegiatan praktek ini, dibuktikan dengan hasil analisis rekapan nilai evaluasi topik belajar, yang tertinggi pada aspek pemahaman dengan kategori sangat kurang dan kurang tidak ada peserta dari 37 orang peserta, 2 orang (sedang), 5 orang (baik), dan 30 orang (sangat baik). Sedangkan kategori yang rendah pada aspek ke-4 (kemampuan mengkomunikasikan materi praktek dengan pihak lain), dari 37 peserta, terdapat 1 orang dengan kategori kurang, walaupun terdapat 21 orang yang memiliki kriteria sangat baik untuk mengkomunikasikan hasil praktek dengan pihak lain.
\end{abstract}

Kata Kunci: Fungisida; Nabati; Hama; Pestisida; Sintetik.

\section{ABSTRACT}

Vegetable fungicides are an alternative to solve the damage and disturbance caused by pests and plant diseases on agricultural lands which are easy, efficient, inexpensive, and environmentally friendly to use. In tackling pests and diseases in agricultural areas, many farmers use synthetic pesticides without realizing the residual impact they cause and this is a weakness factor that is often found among farmers in Pandu Village. In addition, their lack of knowledge about the use of plant-based fungicides as an alternative solution for controlling agricultural plant pests. This PKM has specific goals and targets to be achieved, namely increasing the knowledge and skills of farmers and PKK women in the use of vegetable fungicides in increasing banana crop production. The method used in this PKM is a form of counseling 
and training (lectures) as well as the practice of making vegetable fungicides (simulation). This PKM activity was carried out for approximately 8 months. There was an increase in the knowledge and understanding of farmers and PKK women about the negative impact of synthetic pesticides on the environment and humans as well as the use of vegetable fungicides in increasing banana plant production, as evidenced by the results obtained from the pretest and posttest activities, where after completing the material on the activity PKM (Posttest) then from 37 participants there were no more participants who got scores below 50 (0.00\%) compared to before the PKM activity (Pretest), where the percentage value in the 0-50 interval was 97.3\%. There was an increase in the skills of farmers and PKK women in the manufacture of vegetable fungicides as an alternative solution for controlling banana wilt disease due to the attack of the pathogenic fungus Fusarium oxysporum, as evidenced by the enthusiasm of the participants in participating in this practical activity, as evidenced by the results of the analysis of the recap value of the evaluation of learning topics, the highest was in the understanding aspect with very poor and poor categories, there were no participants from 37 participants, 2 people (medium), 5 people (good), and 30 people (very good). While the low category in the 4th aspect (the ability to communicate practical material with other parties), out of 37 participants, there was 1 person in the less category, although there were 21 people who had very good criteria for communicating the results of their practice with other parties.

Keywords: Fungicides; Vegetables; Production; Pesticides; Synthetic.

\section{PENDAHULUAN}

\section{Analisis Situasi}

\section{A. Kondisi Mitra}

Kecamatan Bunaken adalah salah satu Kecamatan yang ada di Kota Manado dengan jumlah penduduk mencapai 21.740 jiwa. Kelurahan Pandu termasuk salah satu Kelurahan yang ada di Kecamatan Bunaken, Kota Manado, dengan jumlah penduduk mencapai 5.604 jiwa (Derek et al., 2017). Kelurahan Pandu secara geografis berbatasan dengan Desa Wori Kabupaten Minahasa Utara (Sebelah Utara), Kelurahan Bengkol Kecamatan Mapanget Kota Manado (Sebelah Timur), Kelurahan Bailang Kecamatan Bunaken dan Kelurahan Bengkol Kecamatan Mapanget Kota Manado (Sebelah Selatan) dan dengan Kelurahan Molas Kecamatan Bunaken Kota Manado (Sebelah Barat).

Kelurahan Pandu memiliki luas wilayah sekitar 896 Ha yang terdiri dari 8 lingkungan, yang mempunyai luas persawahan 5,0 Ha dan perkebunan/perladangan $630,28 \mathrm{Ha}, \quad$ luas tanaman pangan terbesar adalah jagung sekitar $315 \mathrm{Ha}$, dengan jumlah petani 400 orang dan buruh tani sekitar 201 orang. Besarnya luas pertanian dan banyaknya petani di Kelurahan
Pandu tersebut memungkinkan adanya penggunaan pestisida dalam rangka mengendalikan hama dan penyakit tumbuhan yang dewasa ini kerusakan yang ditimbulkan oleh hama dan penyakit tumbuhan dilahan-lahan pertanian sudah menjadi masalah yang serius di dunia pertanian.

Berbagai upaya telah dilakukan untuk mengendalikan hama dan penyakit ini baik dengan cara tradisional maupun dengan cara modern yaitu penggunaan pestisida.

Pada tahun permulaan program intensifikasi pangan, masalah hama dan penyakit diusahakan dengan penanganan secara kimiawi yakni menggunakan pestisida. Menurut Pattiselanno (2001) maka manusia sejak dahulu berusaha untuk mengurangi/menekan laju kerusakannya dengan menggunakan berbagai cara, baik yang bersifat tradisional maupun yang sudah modern yaitu pestisida. Demikian juga yang dilakukan banyak orang khususnya petani di Kelurahan Pandu, mereka berusaha menekan ataupun mengurangi tingkat kerusakannya dengan pestisida.

Dibandingkan dengan teknik-teknik pengendalian hama dan penyakit lainnya, penggunaan pestisida oleh sebagian besar petani 
JPAI

Jurnal Perempuan dan Anak Indonesia

dianggap lebih efektif, penggunaannya lebih praktis, dan mendatangkan keuntungan ekonomi yang besar (Untung, 2006). Berbagai jenis pestisida telah digunakan sejak senyawa ini dikenal sebagai senjata ampuh untuk membasmi hama dan penyakit tanaman (Noya, 2004).

Dampak dari aplikasi pestisida sintetik secara langsung dapat berupa residu yang melekat pada hasil tanaman dan secara tidak langsung akan mengganggu kesehatan konsumen, pencemaran lingkungan, serta membunuh organisme lainnya yang bukan sasaran (Arwiyanto, 2003 dalam Purwantisari et al., 2008).

Betapa besarnya ketergantungan petani terhadap pestisida dan betapa besar resiko yang dihadapi petani dalam menggunakan pestisida. Keracunan pestisida dapat terjadi di kalangan petani di Kelurahan Pandu Kecamatan Bunaken diakibatkan karena cara penggunaannya yang sembarangan dan kurangnya pemahaman terhadap efek buruk yang ditimbulkannya. Petani dalam hal ini memiliki kedudukan ganda yaitu sebagai pelaku dan penderita keracunan pestisida.

Alternatif pengendalian penyakit tanaman yang ramah lingkungan adalah dengan menggunakan fungisida alami dari mikroba antagonis dan ekstrak tumbuhan. Penggunaan fungisida nabati selain dapat menghambat perkembangan penyakit juga aman bagi konsumen dan lingkungan karena mudah terurai dan tidak meninggalkan residu pada produk pertanian (Sudarmo, 2005), bahannya mudah didapat, dan harga relatif lebih murah (Dadang dan Ohsawa, 2000).

Mitra yang akan dirangkul dalam kegiatan ini adalah: Petani dan Ibu-Ibu PKK Kelurahan Pandu yang mempunyai potensi dalam menggerakkan perekonomian keluarga yang bisa memiliki bekal pengetahuan dalam penggunaan pestisida secara terkendali untuk mengurangi tingkat keracunan yang diakibatkannya dalam rangka menanggulangi hama dan penyakit tumbuhan serta meningkatkan produksi pertanian kearah yang lebih baik lagi, dan dapat meningkatkan pengetahuan petani dalam
Volume 3 Nomor 1, [ September 2021 ] hal 7-14 ISSN 2686-2891 DOI: https://doi.org/10.35801/jpai.3.1.2021.36738

menggunakan fungisida nabati yang ramah lingkungan. Oleh karena itu diperlukan adanya penyuluhan dan pelatihan cara pemanfaatan fungisida nabati dalam peningkatan produksi tanaman pertanian.

\section{B. Peran Mitra dalam Lingkungan}

Para petani dan Ibu-Ibu PKK merupakan kelompok masyarakat yang keberadaan dan kegiatannya mempunyai pengaruh yang besar bagi perkembangan, peningkatan, dan pergerakkan bagi perekonomian keluarga dan masyarakat yang ada di Kelurahan Pandu, Kecamatan Bunaken, Kota Manado.

\section{Tujuan dan Manfaat Kegiatan}

Adapun tujuan dan manfaat dari kegiatan PKM ini yaitu antara lain:

Peningkatan pengetahuan dan keterampilan dalam penggunaan dan pembuatan fungisida nabati sebagai salah satu alternatif pengendalian penyakit layu pada tanaman pisang.

Peningkatan kesadaran masyarakat akan bahaya dan dampak samping yang negatif dari residu pestisida sintetik bagi lingkungan dan manusia, agar terpola cara penggunaan pestisida berbahan alami seperti fungisida nabati yang penggunaan dan aplikasinya secara baik dan benar untuk mengurangi tingkat keracunan pestisida sintetik yang diakibatkannya.

\section{METODE PELAKSANAAN}

\section{Sasaran kegiatan}

Yang menjadi sasaran dalam kegiatan PKM ini adalah para Petani dan Ibu-Ibu PKK yang merupakan kelompok masyarakat yang keberadaan dan kegiatannya mempunyai pengaruh yang besar bagi perkembangan, peningkatan, dan pergerakkan bagi perekonomian keluarga dan masyarakat yang ada di Kelurahan Pandu, Kecamatan Bunaken, Kota Manado.

\section{Lokasi kegiatan}


JPAI

Jurnal Perempuan dan Anak Indonesia

Lahan Perkebunan Tanaman Pisang yang ada di Kelurahan Pandu, Kecamatan Bunaken, Kota Manado.

\section{Metode yang digunakan :}

\section{Pemberian Teori/Ceramah}

Adapun solusi yang di tawarkan untuk mengatasi permasalahan kurangnya pengetahuan petani tentang pestisida dan dampak yang ditimbulkannya dan manfaat dari fungisida nabati, maka perlu dilakukan penyuluhan dan pelatihan pembuatan dan penggunaan fungisida nabati yang ramah lingkungan. Pemberian materi teori melalui metode ceramah, dengan materi yang meliputi:

a. Tinjauan umum/pengertian pestisida.

b. Bahaya/efek samping pestisida terhadap kehidupan mikroba tanah.

c. Mekanisme toksisitas pestisida.

d. Tinjauan umum perilaku petani dalam menggunakan pestisida

e. Penggunaan pestisida yang baik dan benar

f. Tinjauan umum/pengertian pestisida nabatisida nabati

g. Jenis-jenis fungisida nabati

h. Manfaat fungisida nabati.

\section{Praktek Pembuatan dan Penggunaan} Fungisida Nabati

Praktek pembuatan dan penggunaan fungisida nabati dilakukan dengan menggunakan metode simulasi. Kegiatan praktek meliputi:

a. Pembuatan fungisida nabati: dibuat dari daun tanaman Jeruk, Sirsak, dan Cengkih.

\section{Maserasi}

2. Ekstrak kasar fungisida nabati

b. Pengujian fungisida nabati secara invitro

1. Metode Umpan Beracun

2. Metode Kertas Saring

c. Aplikasi fungisida nabati di lahan tanaman pisang.

\section{HASIL DAN PEMBAHASAN}

Produk yang dihasilkan dari kegiatan PKM yang dinilai bermanfaat:
Volume 3 Nomor 1, [ September 2021 ] hal 7-14 ISSN 2686-2891 DOI: https://doi.org/10.35801/jpai.3.1.2021.36738

Peningkatan pemahaman dan pengetahuan mitra tentang penggunaan fungisida nabati dan dampak yang ditimbulkannya adalah merupakan produk kegiatan yang dihasilkan dalam PKM ini. Untuk mendapatkan gambaran keberhasilan yang diperoleh dalam kegiatan PKM ini maka dilaksanakan kegiatan Pretest (sebelum PKM berlangsung) dan Posttest (setelah PKM berlangsung). Dari kedua kegiatan ini, maka nilai perbandingan antara pretest dan posttest dapat digunakan untuk mengukur tingkat perubahan pemahaman dan pengetahuan mitra dalam penggunaan fungisida nabati.

Selain produk peningkatan pemahaman dan pengetahuan mitra dalam penggunaan fungisida nabati di atas, juga diperoleh peningkatan keterampilan mitra dalam membuat ekstrak fungisida nabati untuk meningkatkan produktivitas tanaman pisang dalam pengendalian penyakit Layu Fusarium yang disebabkan oleh jamur Fusarium oxysporum.

Dengan kegiatan PKM ini maka solusi pemecahan permasalahan adanya penyakit akibat jamur patogen pada tanaman pisang bisa teratasi dengan memanfaatkan Fungisida Nabati sebagai upaya pengendalian yang ramah lingkungan dibandingkan dengan pengendalian dengan menggunakan pestisida sintetik.

Keberhasilan dari kegiatan PKM ini dipantau lewat kegiatan Pretest dan Posttest serta Evaluasi Topik Belajar. Semuanya diukur berdasarkan nilai persentase akhir yang dihasilkan. Hasil pelatihan dari kegiatan PKM ini terukur lewat adanya keterampilan peserta dalam membuat ekstrak fungisida nabati, hal ini dipantau langsung lewat evaluasi dan monitoring yang dilakukan.

\section{Hasil Kegiatan Pretest (sebelum PKM berlangsung) \\ Sebelum kegiatan PKM berlangsung,} terlebih dahulu dilakukan pretest kepada 37 orang peserta untuk mengukur sejauh mana peserta mengetahui dan memahami tentang penggunaan dan cara pembuatan ekstrak 
JPAI

Jurnal Perempuan dan Anak Indonesia

fungisida nabati. Hasil pretest terukur lewat jawaban peserta terhadap 10 soal pilihan berganda yang dikerjakan selama 10 menit dan 5 soal essay yang dikerjakan selama 5 menit, total waktu pengerjaan 15 menit yang disodorkan kepada 37 peserta tersebut.

Jawaban yang diberikan oleh 37 peserta tersebut diukur dan dianalisis. Berdasarkan hasil pengukuran dan analisis, maka diperoleh persentase nilai tertinggi pada interval nilai 0 11 dengan jumlah peserta 13 orang (35.13\%). Sedangkan persentase nilai terendah pada interval nilai 51-60 dengan jumlah peserta 1 orang $(2.70 \%)$. Keseluruhan hasil pretest tersaji dalam Tabel 1. Dari data Tabel 1 ini menunjukkan bahwa hanya ada satu orang saja peserta yang mendapatkan nilai di atas 50 pada interval nilai $51-60 \quad(2.70 \%)$. Hal ini menunjukkan bahwa 37 orang peserta yang mengikuti kegiatan PKM ini belum memahami dan mengetahui penggunaan dan cara pembuatan ekstrak fungisida nabati.

Tabel 1. Hasil Pretest Sebelum PKM Berlangsung

\begin{tabular}{|c|c|c|c|}
\hline No & $\begin{array}{c}\text { Interval } \\
\text { Nilai }\end{array}$ & $\begin{array}{c}\text { Jumlah } \\
\text { (Orang) }\end{array}$ & $\%$ \\
\hline 1 & $0-10$ & 13 & 35.13 \\
\hline 2 & $11-20$ & 7 & 18.92 \\
\hline 3 & $21-30$ & 8 & 21.63 \\
\hline 4 & $31-40$ & 2 & 5.40 \\
\hline 5 & $41-50$ & 6 & 16.22 \\
\hline 6 & $51-60$ & 1 & 2.70 \\
\hline 7 & $61-70$ & 0 & 0.00 \\
\hline 8 & $71-80$ & 0 & 0.00 \\
\hline 9 & $81-90$ & 0 & 0.00 \\
\hline 10 & $91-100$ & 0 & 0.00 \\
\hline & Jumlah & 37 & 100.00 \\
\hline
\end{tabular}

\section{Hasil Kegiatan Posttest (setelah PKM} berlangsung)

Hasil kegiatan posttest adalah merupakan kunci dalam mengukur keberhasilan dari kegiatan PKM ini. Peserta diperkenalkan terlebih dahulu tentang materi pelatihan mengenai tinjauan umum/pengertian pestisida,
Volume 3 Nomor 1, [ September 2021 ] hal 7-14 ISSN 2686-2891 DOI: https://doi.org/10.35801/jpai.3.1.2021.36738

bahaya/efek samping pestisida sintetik terhadap lingkungan dan manusia, tinjauan umum/pengertian pestisida nabati, jenis-jenis pestisida nabati, pengertian metabolit sekunder tanaman, pengertian senyawa bioaktif, dan manfaat pestisida nabati. Setelah pemberian materi, seperti halnya kegiatan pretest, 37 orang peserta diberikan 10 soal pilihan berganda dan 5 soal essay dengan durasi waktu pengerjaan soal selama 15 menit.

Berdasarkan hasil pengukuran dan analisis, diperoleh persentase tertinggi pada interval nilai 71-80 (45.94\%) dengan 17 orang peserta dan yang terendah pada interval nilai 81-90 (10.82\%) dengan 4 orang peserta. Dari Tabel 2 di bawah ini, terlihat bahwa dari 37 peserta PKM tidak ada lagi peserta yang mendapatkan nilai di bawah 50 bahkan pun ada 9 orang peserta yang berada pada interval nilai tertinggi yaitu 91-100 (24.32), hal ini menunjukkan telah terjadi kenaikan pemahaman sebesar $21.62 \%$ dan itu berarti pula bahwa materi yang diberikan dapat diserap, dimengerti, dipahami, dan dipraktekkan oleh peserta kegiatan PKM.

Tabel 2. Hasil Posttest Setelah PKM Berlangsung

\begin{tabular}{|c|c|c|c|}
\hline No & $\begin{array}{c}\text { Interval } \\
\text { Nilai }\end{array}$ & Jumlah (Orang) & $\%$ \\
\hline 1 & $0-10$ & 0 & 0.00 \\
\hline 2 & $11-20$ & 0 & 0.00 \\
\hline 3 & $21-30$ & 0 & 0.00 \\
\hline 4 & $31-40$ & 0 & 0.00 \\
\hline 5 & $41-50$ & 0 & 0.00 \\
\hline 6 & $51-60$ & 0 & 0.00 \\
\hline 7 & $61-70$ & 7 & 18.92 \\
\hline 8 & $71-80$ & 17 & 45.94 \\
\hline 9 & $81-90$ & 4 & 10.82 \\
\hline 10 & $91-100$ & 9 & 24.32 \\
\hline \multicolumn{2}{|c|}{ Jumlah } & 37 & 100.00 \\
\hline
\end{tabular}

Hasil yang diperoleh dari kegiatan pretest dan posttest menggambarkan bahwa kegiatan PKM ini berhasil menambah wawasan, pengetahuan, pemahaman, dan keterampilan peserta dalam penggunaan dan pembuatan 


\section{JPAI}

Jurnal Perempuan dan Anak Indonesia

ekstrak fungisida nabati. Nilai persentase pretest dan posttest secara keseluruhan disajikan dalam Tabel 3. Dari data Tabel 3 di bawah ini, ternyata hasil persentasenya mengalami kenaikan.

Tabel 3. Nilai Persentase Pretest Dan Posttest

\begin{tabular}{|c|c|c|c|c|c|}
\hline \multirow{2}{*}{ No } & \multirow{2}{*}{ Interval } & \multicolumn{2}{|c|}{ Pretest } & \multicolumn{2}{c|}{ Postest } \\
\cline { 3 - 6 } & & $J \mathrm{~mL}$ & 96 & Jml & $\%$ \\
\hline 1 & $0-10$ & 3 & 35.13 & 0 & 0.00 \\
\hline 2 & $11-20$ & 17 & 18.92 & 0 & 0.00 \\
\hline 3 & $21-30$ & 8 & 21.63 & 0 & 0.00 \\
\hline 4 & $31-40$ & 2 & 5.40 & 0 & 0.00 \\
\hline 5 & $41-50$ & 6 & 16.22 & 0 & 0.00 \\
\hline 6 & $51-60$ & 1 & 2.70 & 0 & 0.00 \\
\hline 7 & $61-70$ & 0 & 0.00 & 7 & 18.92 \\
\hline 8 & $71-80$ & 0 & 0.00 & 17 & 45.94 \\
\hline 9 & $81-90$ & 0 & 0.00 & 4 & 10.82 \\
\hline 10 & $91-100$ & 0 & 0.00 & 9 & 24.32 \\
\hline \multicolumn{2}{|c|}{ Jumblah } & 37 & 100.00 & 37 & 100.00 \\
\hline
\end{tabular}

Data yang tersaji dalam Tabel 3 di atas dan Gambar 1 di bawah ini, memperlihatkan bahwa pada saat selesai kegiatan posttest, sudah tidak ada lagi peserta yang mendapatkan nilai di bawah $50(0,00 \%)$ dibandingkan pada saat pretest (sebelum PKM berlangsung), peserta belum mendapatkan materi pelatihan sehingga nilai persentase pada interval nilai 0-50 sebesar $97.3 \%$. Hal ini berarti materi yang diberikan dapat diserap peserta dengan baik.



Gambar 1. Perbandingan Nilai Persentase Pretest Dan Posttest

3. Hasil Praktek Pembuatan Fungisida Nabati

Pada kegiatan PKM ini metode yang digunakan dalam praktek pembuatan fungisida
Volume 3 Nomor 1, [ September 2021 ] hal 7-14 ISSN 2686-2891 DOI: https://doi.org/10.35801/jpai.3.1.2021.36738

nabati yaitu memperagakan atau mensimulasikan cara-cara pembuatan ekstrak fungisida nabati dari daun pepaya, sirsak, dan cengkih (untuk mendapatkan metabolit sekunder/senyawa bioaktif dari tanaman tersebut) dan bagaimana aplikasinya di lapangan.

Praktek yang dilakukan diawali dengan maserasi yaitu pertama daun yang telah diambil tersebut lalu dibersihkan dan dicuci menggunakan aquades. Serbuk kering dari masing masing daun dimaserasi dengan etanol 96\% perbandingan 1:5 (w/v). Campuran ini kemudian dikocok, kemudian diendapkan, disaring sehingga memperoleh filtrat ke-1 dan ampas. Kemudian ampas dilarutkan kembali dengan pelarut etanol $96 \%$. Selanjutnya disaring untuk memperoleh filtrate ke-2 dan ampas, lalu filtrat digabung (1 dan 2), dan dipekatkan hingga diperoleh ekstrak kasar (krud).

Larutan ekstrak fungisida yang telah diperoleh dari 3 macam daun tersebut kemudian dilakukan pengujian secara invitro di dalam laboratorium yaitu dengan menggunakan metode umpan beracun dan metode kertas saring yang selanjutnya diaplikasikan pada tanaman pisang yang terinfeksi penyakit layu akibat adanya serangan jamur Fusarium oxysporum.

Hasil yang diperoleh dari kegiatan praktek ini yaitu antusiasnya peserta dalam mengikuti praktek ini sangat tinggi terbukti dari keaktifan peserta dalam bertanya ketika simulasi berlangsung, hal ini diketahui dengan jawaban yang diberikan pada saat pengisian Lembar Evaluasi Topik Belajar pada saat praktek selesai dilaksanakan, hal ini dilakukan dengan tujuan untuk mengukur sejauh mana peserta dapat menyerap materi praktek ini.

Hasil analisis evaluasi topik belajar ini memperlihatkan bahwa tingkat pemahaman peserta akan materi praktek pembuatan fungisida nabati adalah yang tertinggi kategorinya, dari rekapan 37 peserta, kategori sangat kurang dan kurang tidak ada peserta, 2 
JPAI

Jurnal Perempuan dan Anak Indonesia

orang (sedang), 5 orang (baik), dan 30 orang (sangat baik).

Sedangkan untuk kategori yang rendah terdapat pada aspek ke-4 yaitu kemampuan mengkomunikasikan materi praktek dengan pihak lain, dimana dari 37 peserta terdapat 1 orang dengan kriteria kurang, walaupun terdapat 21 orang yang memiliki kriteria sangat baik untuk mengkomunikasikan materi praktek dengan orang lain. Secara keseluruhan hasil analisis evaluasi topik belajar peserta disajikan pada Tabel 5 dan Gambar 2 di bawah ini.

Gambaran hasil analisis yang terlihat pada Tabel 4 dan Gambar 2 di bawah ini terlihat bahwa kriteria yang tertinggi terdapat pada aspek pemahaman akan materi praktek dibadingkan dengan yang lainnya. Hal ini diduga disebabkan oleh keaktifan peserta yang luar biasa tinggi ditandai dengan motivasi peserta yang besar, dari 37 peserta terdapat 27 orang (sangat baik) motivasinya dengan rasa ingin tahu yang tinggi akan bagaimana cara membuat fungisida nabati (terutama Ibu-Ibu PKK) yang memiliki banyaknya pertanyaan selama diskusi berlangsung dan memiliki ideide kreatif dan keterampilan dalam membuat fungisida nabati yang tinggi.

Motivasi peserta sangat besar di atas juga ditunjang dengan kemampuan yang besar dalam mengkomunikasikan materi praktek kepada orang lain bahkanpun dalam berkomunikasi dengan pemandu, walaupun terdapat 1 orang peserta yang memiliki kemampuan berkomunikasi dengan orang lain yang kurang, hal ini disebabkan karena terdapatnya kendala dari dalam dirinya sendiri (peserta tersebut).

Hal ini terbukti dengan ketidakaktifannya di dalam kegiatan praktek, setelah diamati ternyata peserta tersebut memiliki sifat pemalu dan pendiam. Hal inilah yang membuatnya kesulitan dalam berkomunikasi bahkanpun dalam mengajukan pertanyaan dan pendapat selama diskusi dan berkomunikasi dengan pemandu materi.

Tabel 4. Hasil Rekapan Evaluasi Topik Belajar (Praktek)
Volume 3 Nomor 1, [ September 2021 ] hal 7-14 ISSN 2686-2891 DOI: https://doi.org/10.35801/jpai.3.1.2021.36738

\begin{tabular}{|c|c|c|c|c|c|}
\hline \multirow{2}{*}{  } & \multicolumn{5}{|c|}{ Total Kriteria } \\
\hline & $\begin{array}{l}\text { Sangat } \\
\text { Kurang }\end{array}$ & Kurang & Sedang & Baik & $\begin{array}{c}\text { Sangat } \\
\text { Baik }\end{array}$ \\
\hline 1 & 0 & 0 & 2 & 5 & 30 \\
\hline 2 & 0 & 0 & 7 & 9 & 21 \\
\hline 3 & 0 & 0 & 3 & 7 & 27 \\
\hline 4 & 0 & 1 & 2 & 13 & 21 \\
\hline 5 & 0 & 0 & 9 & 10 & 18 \\
\hline
\end{tabular}

Keterangan:

1. Pemahaman anda terhadap materi praktek yang disampaikan pemandu

2. Kesesuaian materi praktek dengan kebutuhan anda

3. Motivasi anda menindaklanjuti semua petunjuk sesuai pelatihan di Desa anda

4. Kemampuan anda mengkomunikasikan hasil praktek pembuatan fungisida nabati dengan pihak lain

5. Keinginan anda berkomunikasi dengan pemandu tentang materi praktek pembuatan fungisida nabati ini

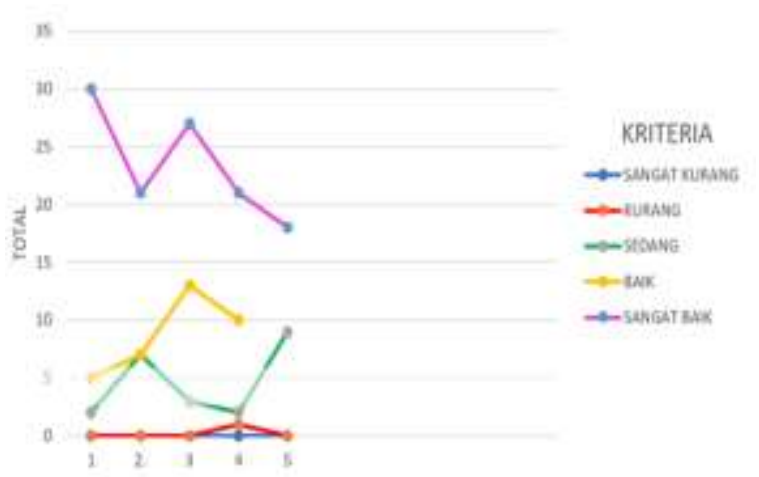

Gambar 2. Hasil Keseluruhan Rekapan Evaluasi Topik Belajar Dalam Kegiatan Praktek

\section{KESIMPULAN DAN SARAN}

\section{Kesimpulan}

a. Terjadi peningkatan pengetahuan dan pemahaman petani dan Ibu-Ibu PKK tentang dampak negatif dari pestisida sintetik bagi lingkungan dan manusia serta pemanfaatan fungisida nabati dalam meningkatkan produksi tanaman pisang, yang dibuktikan dengan hasil yang diperoleh dari kegiatan pretest dan posttest, dimana setelah selesai pemberian materi pada kegiatan PKM (Posttest) maka dari 37 orang peserta sudah tidak ada lagi peserta yang mendapatkan nilai di bawah $50(0.00 \%)$ dibandingkan pada saat sebelum kegiatan PKM (Pretest), dimana 
nilai persentase pada interval nilai $0-50$ sebesar $97.3 \%$.

b. Terjadi peningkatan keterampilan Petani dan Ibu-Ibu PKK dalam pembuatan fungisida nabati sebagai salah satu alternatif solusi pengendalian penyakit layu tanaman pisang akibat serangan jamur pathogen Fusarium oxysporum, yang dibuktikan dengan antusiasnya peserta mengikuti kegiatan praktek ini, dibuktikan dengan hasil analisis rekapan nilai evaluasi topik belajar, yang tertinggi pada aspek pemahaman dengan kategori sangat kurang dan kurang tidak ada peserta dari 37 orang peserta, 2 orang (sedang), 5 orang (baik), dan 30 orang (sangat baik). Sedangkan kategori yang rendah pada aspek ke-4 (kemampuan mengkomunikasikan materi praktek dengan pihak lain), dari 37 peserta, terdapat 1 orang dengan kategori kurang, walaupun terdapat 21 orang yang memiliki kriteria sangat baik untuk mengkomunikasikan hasil praktek dengan pihak lain.

\section{Saran}

Saran yang bisa dikemukakan dalam kegiatan PKM ini antara lain:

a. Sebaiknya sosialisasi dampak negatif dari residu pestisida sintetik bagi lingkungan dan manusia perlu terus dilakukan bagi seluruh masyarakat yang ada di Kelurahan Pandu.

b. Informasi tentang besarnya manfaat fungisida nabati sebagai salah satu pestisida alami yang ramah lingkungan dan bagaimana cara pembuatan fungisida nabati perlu dituangkan dalam suatu petunjuk/pedoman dan disosialisasikan pada masyarakat luas.

c. Perlu ditingkatkan minat dan semangat masyarakat dalam menunjang peningkatan pemanfaatan fungisida nabati sebagai salah satu alternatif solusi pemecahan permasalahan yang dihadapi masyarakat dalam mengendalikan penyakit layu tanaman pisang akibat adanya sarangan jamur pathogen Fusarium oxysporum agar produktivitas tanaman pisang dapat meningkat.

\section{UCAPAN TERIMAKASIH}

Terima kasih Tim Penulis ucapkan kepada Pimpinan Universitas Sam Ratulangi Manado dan Pimpinan LPPM Unsrat Manado, yang telah mendanai kegiatan ini melalui Skim Program Kemitraan Masyarakat (PKM) dana PNBP tahun anggaran 2021.

\section{DAFTAR PUSTAKA}

Dadang dan Ohsawa, K. 2000. Penghambatan aktivitas makan larva Plutella xylostella (L). (Lepidoptera: Yponomeutidae) yang diperlakukan ekstrak biji Swietenia mahogany JACQ (Meliaceae). Bul. Hama dan Penyakit Tumbuhan. 1:27-32.

Derek Marhaeny Ketty, Rine Kaunang, Joachim N.K Dumais,. 2017. Analisis Keuntungan Agroindustri Gula Aren Di Kelurahan Pandu, Kecamatan Bunaken, Kota Manado. AgriSosioEkonomiUnsrat, ISSN 1907-4298, Volume 13 Nomor 3A, November 2017: 341 350. https://ejournal.unsrat.ac.id/index.php/jis ep/article/view/18552/18078 [Diakses pada tanggal 29 Oktober 2019].

Noya, A.I. 2004. Residu Insektisida Profenofos Pada Sayuran Kubis Dan Tanah Andosol Rurukan Kecamatan Tomohon. Tesis. Program Pasca Sarjana Universitas Samratulangi Manado.

Pattiselanno, A.E. 2001. Analisis Sikap dan Perilaku Terhadap Sasi Pada Masyarakat Pulau Saparua Kabupaten Maluku Tengah. Eugenia. 7(4) : 282288.

Purwantisari S, R.S. Ferniah, dan B. Raharjo. 2008. Pengendalian Hayati Penyakit Lodoh (Busuk Umbi Kentang) Dengan Agens Hayati Jamur-Jamur Antagonis Isolat Lokal. Bioma. 10(2): 13-19.

Sudarmo, S. 2005. Pestisida Nabati: Pembuatan dan Pemanfaatannya. Kanisius, Yogyakarta.

Untung, K. 2006. Pengantar Pengelolaan Hama Terpadu (edisi kedua). Penerbit Gadjah Mada University Press. Yogyakarta. 